DOI: $10.33067 /$ SE.3.2021.6

Iryna Gerlach *

Lilia Ukraynets $\star \star$

\title{
The Impact of Remittances of Ukrainian Migrants on the Stabilisation of the Economy During the Covid Crisis
}

\begin{abstract}
International labour migration is a global process that has affected the populations of all countries and continents. Today, migrants face a new additional barrier - the COVID-19 pandemic, which has drastically affected all forms of human mobility. Today, labour-based migration from Ukraine is directed mainly to EU Member States. The main motives for international labour migration is the potential of earning money, financial security of the family etc. Accordingly, the consequence of international migration is the inflow of money into the country of migrant origin. Remittances from migrant workers are an important source of income for Ukraine. Despite the COVID-19 pandemic, there has been an increase in migrant remittances, contributing to the development of households, human potential, the reduction of poverty and inequality, and the inflow of foreign currency. This article proposes an econometric model of the impact of migrant remittances on the stabilisation of the country's economy during the pandemic. As a result of the calculations, it was found that the income from people working abroad initially reduces the deviation of GDP from the equilibrium trend, but over time there is a clear procyclical impact. This feature is favourable for the Ukrainian economy and may mean that migrant transfers in times of crisis help to overcome the effects of global economic downturns.
\end{abstract}

Keywords: Labour Migration, Remittances, Migration, Ukrainians, European Union, COVID-19, Crisis

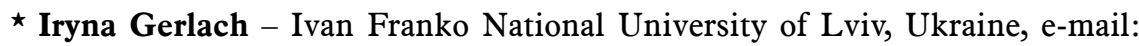
iryna.yeleyko@lnu.edu.ua, ORCID: 0000-0001-6568-5870.

$\star \star$ Lilia Ukraynets - Ivan Franko National University of Lviv, Ukraine, e-mail: liliya.ukrayinets@lnu.edu.ua, ORCID: 0000-0002-3436-5556. 


\section{Introduction}

Today, international migration has become a global process that has affected people in all countries and on all continents. Today, migrants face a new problem - the COVID-19 pandemic, which has drastically affected all forms of human mobility. It is the COVID crisis, as the most acute crisis of today, that is the main problem for international migrants in combination with its consequences: a threat to life, a global economic downturn, a reduction of migration flows, crises in the medical sphere, and governments facing additional challenges including finding solutions to offset economic downturns. In addition, international migration processes during the COVID-19 crisis are characterised by the following features: low demand for labour, and hence a decline in employment; persistent severe travel restrictions; and declining income. In addition to migrant workers, other categories of international migrants, such as refugees and asylum seekers, face problems. Wars, cataclysms, natural disasters, and other disasters continue, but due to the pandemic, recipient countries have stopped accepting those migrants.

The COVID-19 pandemic has hit many industries harder than the 2008 financial crisis, and most industries will need more time to recover. Tourism has almost come to a halt due to border closures, quarantine, and entry bans. Business trips and vacations have changed format, as video conferencing replaces face-to-face business meetings. ${ }^{1}$

As shown by foreign studies, ${ }^{2}$ the lack of an expected strong link between a migrant's remittances and long-term economic growth can be explained by the lack of any proper investment impact of private transfers due to a number of reasons: a) high marginal propensity to consume, especially given the permanent nature of remittances; replacing labour contribution with unearned income, c) reducing the efficiency of local investors, d) creating pressure to maintain an inefficient banking system, e) weakening the critical assessment of government policy, g) the deteriorating quality of institutions.

1 R. Berger, Latest update of our corona economic impact series, 24.04.2020, https:// www.rolandberger.com/en/Insights/Publications/This-crisis-is-different-Comparing-the-coronavirus-crisis-with-the-financial.html (access 2.06.2021).

2 Migration and Remittances: Eastern Europe and the Former Soviet Union, eds. A. Mansoor, B. Quillin, Washington 2009; A. Barajas et al., Do Workers' Remittances Promote Economic Growth?, IMF Working Paper WP/09/153, International Monetary Fund, Washington 2009; M. Bakker, Migrating into Financial Markets: How Remittances Became a Development Tool, University of California Press, Oakland 2015. 


\section{The Impact of the COVID Crisis on the Structure of International Migration Flows}

The COVID crisis has shaken the whole world and has spread to all corners of our planet. A causal link can be traced between the crisis phenomena. For example, the outbreak of COVID-19 in January 2020 was first classified as an extreme situation which quickly escalated into a natural crisis. It then went on to cause the economic and psychological crises that people around the world now are suffering from. ${ }^{3}$

At this stage, it is still too early to scope the full range of the pandemic's impact on migration trends, but some signs indicate that the COVID crisis has significantly reduced the number of international migrants compared to the forecasts; approximate estimates indicate a $27 \%$ reduction in these flows compared to analyses performed before the COVID-19 pandemic. Although the actual number of international migrants increased from 272 million people in 2019 to 281 million people in $2020,{ }^{4}$ it was the COVID crisis and the measures taken by the countries that prevented to an even greater extent the trend of increasing the expected volume of movement. The changing flows of international migrants reflect the growing diversification of economic opportunities available to migrant workers and imply greater competition that destination countries will face in attracting migrants in the future, especially highly-skilled migrants.

Migrant workers are at the forefront of the crisis. They make up a significant proportion of the OECD's medical workforce, with those workers constituting one in four OECD doctors and one in six nurses. In many OECD countries, more than a third of the workforce in other key sectors such as transport, cleaning, food production, and IT services, are immigrants. ${ }^{5}$

Given the uncertainty about the situation in the near future, it is too early to assess the influence on immigrants and their role for host countries,

3 R. Zvarych, T. Tysh, Upravlinnia kryzovymy sytuaciiamy ta liderstvo $v$ umovakh koronakryzy (Управління кризовими ситуачіями та лідерство в умовах коронакризи), "Visnyk Ternopilskoho natsionalnoho ekonomichnoho universytetu", № 2/2020, pp. 135-147, http://visnykj.wunu.edu.ua/index.php/visnykj/article/download/1108/1213 (access 8.06.2021).

${ }^{4}$ Global Migration Growth Slowed by 27 Per Cent in 2020, Following Decades of Robust Increase, Annual Report Finds. United Nations. Meetings Coverage and Press Releases, 15.01.2021, https://www.un.org/press/en/2021/dev3436.doc.htm (access 7.06.2021).

5 OECD Policy Responses to Coronavirus (COVID-19) What is the impact of the COVID-19 pandemic on immigrants and their children?, OECD, 19.10.2020, http://www. oecd.org/coronavirus/policy-responses/what-is-the-impact-of-the-covid-19-pandemic-on-immigrants-and-their-children-e7cbb7de/ (access 30.07.2021). 
but the facts clearly indicate a disproportionate impact. Immigrants have been hit particularly hard in Southern Europe, Ireland, and Austria, where employment has fallen by at least 4 percentage points, at least twice as much as their indigenous counterparts.

Exceptions with regard to the decline in immigrant employment include the United Kingdom, the Netherlands, Finland, and the Czech Republic.

\section{The Consequences of the COVID-19 Pandemic for Ukrainian Migrant Labourers}

Significant remittances from migrant workers mitigate the effects of crises on labour-donor countries. Unlike other financial flows, remittances are quite stable, as migrant workers try to support their families in difficult times. In addition, such flows recover quickly after a crisis.

Since 2000, the labour emigration from Ukraine has been directed mainly to EU Member States. Among the non-European countries accepting a significant flow of Ukrainian migrants was Russia. Russian aggression in 2014 has led to a significant redistribution of migrant workers by country; the EU countries' share has increased whereas Russia's has decreased (at least by a third). At the same time, the share of informal money transfer channels has significantly increased against the background of higher prices for payment system services, ease of transport connections, and geographical proximity of countries. ${ }^{6}$ Among the EU members, Poland is the country to which most migrant workers have gone.

Thus, today the EU members make up the largest region for the employment of migrants from Ukraine. Three out of four Ukrainian migrant labourers in 2017 worked in the EU. ${ }^{7}$ The mobility of Ukrainians to EU Member States is also facilitated by agreements on small border traffic concluded with Hungary in 2007, Poland and Slovakia in 2008, and Romania in 2014.

6 T. Tokarchuk, Perekazy vid trudovykh mihrantiv: potochna sytuaciia ta ocinka perspektyv.Natsionalnyi bank Ukrainy (Перекази від трудових мігрантів: поточна ситуація та оцінка перспектив. Національний банк України), https://bank.gov.ua/admin_uploads/article/Transfers_from_migrant_workers_Tokarchuk_2020-06-03.pdf?v $=4$ (access 2.06.2021).

7 D. Zakha, M. Luke, Kincia-kraiu ne vydno: trudova mihraciia z Ukrainy mozhe spovilnytysia, prote, shoydshe za vse tryvatymе (Кіния-краго не видн: трудова міграчіл 3 України може сповільнитися, проте, швидше за все, триватиме), https://voxukraine. org/uk/kintsya-krayu-ne-vidno-trudova-migratsiya-z-ukrayini-mozhe-spovilnitisyaprote-shvidshe-za-vse-trivatime/ (access 8.06.2021). 
A survey of migrant workers has made it possible to establish a hierarchy of motives that determine travelling abroad: ${ }^{8}$

- the opportunity to generate earnings to improve living conditions (buying an apartment or building a house), buying a car or other durable goods;

- the opportunity to generate earnings to meet current living needs food, the purchase of necessary everyday goods (clothing, etc.);

- the accumulation of funds to pay for their children's education in higher education institutions;

- the accumulation of start-up capital for starting their own business or developing their businesses;

- motives of an intangible nature (to see the world, to acquire certain work skills, to improve language skills, etc.).

Despite the diversity of estimates of the labour migration scale, they all show that trips to work abroad have become widespread, and have become a source of income for many citizens. And this is obvious because the level of wages in Ukraine is much lower compared to European countries. Although the average monthly wage in Ukraine has risen from $\$ 192$ in 2015 (the lowest during the economic recession) to \$326 in 2018, this is only about a quarter of the average wage in current destination countries such as Poland or the Czech Republic, and less than one-tenth of the wages in the Western and Northern EU Member States. ${ }^{9}$ In other words, the wage gap between Ukraine and other European countries is significant and will remain an incentive for migration for many years to come.

The COVID-19 pandemic has left many domestic migrant workers with a difficult choice; stay abroad and work in unsafe conditions and comply with quarantine restrictions, or to return home where employment is unlikely.

Remittances from migrant workers are one of the positive effects of external labour migration, as they are an important source of foreign exchange for the country. For example, remittances from migrants increased in monetary terms from $\$ 7$ billion in 2015 to $\$ 10$ billion in

8 O. Levtsun, Zovnishnia trudova mihraciia v Ukraini jak demohrafichna problema (Зовнішня трудова міграчія в Україні як демограбічна проблема), http://www.hearts. in.ua/articles/job_search/694.php (access 11.06.2021).

9 D. Zakha, $\bar{M}$. Luke, Kincia-kraiu ne vydno: trudova mihraciia z Ukrainy mozhe spovilnytysia, prote, shoydshe za vse tryvatyme (Кіния-краюо не видн: трудова міграчіл 3 України може сповільнитися, проте, швидше за все, триватиме), https://voxukraine. org/uk/kintsya-krayu-ne-vidno-trudova-migratsiya-z-ukrayini-mozhe-spovilnitisyaprote-shvidshe-za-vse-trivatime/ (access 8.06.2021). 
2018. ${ }^{10}$ On such a scale, remittances are a significant contribution to household income (and hence domestic demand), reducing the current account deficit. According to the National Bank of Ukraine (NBU), in 2019 , the volume of private transfers from abroad amounted to almost $\$ 12$ billion but decreased slightly in 2020 to $\$ 11.8$ billion. ${ }^{11}$ To a large extent, these funds enabled a large part of the population - in particular in the western regions (those which are are tourist regions losing the most because of quarantine measures) - to survive economic troubles.

Remittances from migrant workers have become such a significant part of Ukraine's balance of payments that the NBU has even improved the methodology used to calculate these transfers. Now the NBU is trying to take into account not only official transactions through banks and international payment systems but also information from central banks and financial authorities of other countries - the so-called "mirror statistics". ${ }^{12}$ It allows for the transfer of money through informal channels.

Since 2015, when the NBU start maintaining a record of such things, the largest volumes of private remittances have been carried out from Poland, Russia, the Czech Republic, the United States, and the United Kingdom. Since 2016, it has been Poland which has seen the biggest volume carried out. It was during this period that Russia and Poland reversed their roles; in 2015, Poland provided 19\% of transfers, whereas Russia accounted for $26.4 \% .^{13}$

However, if we take the official data of transactions, the United States and Russia take joint first place, while Poland is in 9th place, behind some European countries and Israel. Data on the private remittances to Ukraine by major destination countries (top 20) are shown in Table 1.

While analysing the volume of private remittances during the COVID-19 pandemic in the context of the main recipient countries of Ukrainian migrants, it's worth noting that no serious structural changes occurred: $27.5 \%$ were remittances from Poland, 9.7\% from Russia, 8.6\% from the Czech Republic, $8.0 \%$ from the United States, and 7.2\% came from the United Kingdom ${ }^{14}$ (Table 1).

10 Ibidem.

11 Natsionalnyi bank Ukrainy. Statystyka zovnishnioho sektoru (Начіональний банк України. Статистика зовнішнього сектору), https://bank.gov.ua/ua/statistic/sectorexternal/data-sector-external (access 28.05.2021).

12 A. Zanuda, Mihranty chy investory: hto bilshe vklade v ekonomiku Ukrainy (Мігранти чи інвестори: хто більше вкладає в економіку України?), ВВС Ukraina, https://www.bbc.com/ukrainian/features-45473686 (access 1.06.2021).

${ }_{13}$ Ibidem.

14 Natsionalnyi bank Ukrainy..., op.cit. 
I. Gerlach, L. Ukraynets, The Impact of Remittances of Ukrainian Migrants...

Table 1. Volumes of private remittances to Ukraine by major countries, in millions USD

\begin{tabular}{|l|r|r|r|r|r|r|}
\hline Countries & \multicolumn{1}{|c|}{$\mathbf{2 0 1 5}$} & $\mathbf{2 0 1 6}$ & $\mathbf{2 0 1 7}$ & \multicolumn{1}{|c|}{$\mathbf{2 0 1 8}$} & \multicolumn{1}{c|}{$\mathbf{2 0 1 9}$} & \multicolumn{1}{c|}{$\mathbf{2 0 2 0}$} \\
\hline World & $\mathbf{6 9 5 9}$ & $\mathbf{7 5 3 5}$ & $\mathbf{9 2 6 4}$ & $\mathbf{1 1 1 1 1}$ & $\mathbf{1 1 9 2 1}$ & $\mathbf{1 1 8 8 8}$ \\
\hline including: \\
\hline Poland & 1329 & 1991 & 3116 & 3649 & 3558 & 3061 \\
\hline Russia & 1835 & 1396 & 1292 & 1091 & 1266 & 1010 \\
\hline Czech Republic & 314 & 377 & 435 & 846 & 1113 & 834 \\
\hline USA & 516 & 576 & 679 & 870 & 984 & 1220 \\
\hline UK & 245 & 259 & 311 & 394 & 601 & 1013 \\
\hline Italy & 350 & 412 & 447 & 492 & 498 & 475 \\
\hline Germany & 270 & 291 & 318 & 426 & 462 & 513 \\
\hline Cyprus & 245 & 249 & 285 & 341 & 391 & 414 \\
\hline Israel & 108 & 171 & 280 & 337 & 351 & 361 \\
\hline Greece & 191 & 179 & 178 & 191 & 195 & 195 \\
\hline $\begin{array}{l}\text { Virgin Islands } \\
\text { (Brit.) }\end{array}$ & 35 & 38 & 55 & 157 & 182 & 187 \\
\hline United Arab & 82 & 93 & 120 & 153 & 135 & 145 \\
Emirates & & & & & & 127 \\
\hline Netherlands & 67 & 71 & 98 & 123 & 127 & 192 \\
\hline Singapore & 75 & 73 & 104 & 129 & 120 & 131 \\
\hline Canada & 97 & 73 & 78 & 97 & 95 & 111 \\
\hline Switzerland & 62 & 63 & 76 & 89 & 88 & 86 \\
\hline Spain & 61 & 66 & 76 & 88 & 86 & 96 \\
\hline Turkey & 44 & 57 & 85 & 106 & 79 & 83 \\
\hline Portugal & 43 & 48 & 52 & 57 & 60 & 67 \\
\hline Norway & 952 & 1010 & 1127 & 1420 & 1470 & 1646 \\
\hline Other countries & & & & & & 48 \\
\hline
\end{tabular}

Note: the data are calculated based on bank statements on financial transactions with non-residents of Ukraine and transfers made through international money transfer systems, and take into account the amount of money received through informal channels.

Source: based on data from the National Bank of Ukraine.

In general, more than $60 \%$ of remittances come to Ukraine from EU countries. ${ }^{15}$

In 2008, migrant remittances accounted for $3.4 \%$ of the country's GDP, whereas in 2018 this figure more than doubled to $8.5 \%$, as shown in Figure $1 .{ }^{16}$

\footnotetext{
15 A. Zanuda, op.cit.

${ }^{16}$ Natsionalnyi bank Ukrainy..., op.cit.
} 


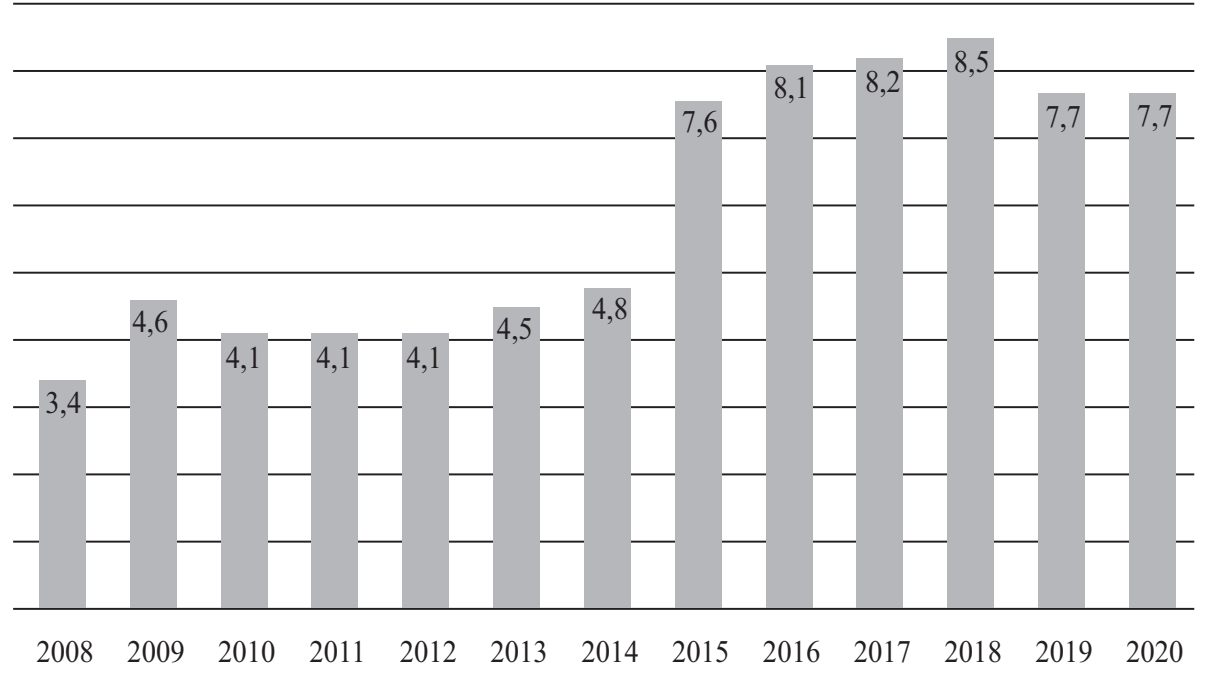

Figure 1. Dynamics of migrants' remittances as a percentage of Ukrainian GDP

Source: based on data from the National Bank of Ukraine.

If ten years ago the volume of remittances from migrants and foreign direct investment were quite comparable, then in the last few years a significant advantage belongs to remittances.

The current business slowdown and the recession could negatively affect migrant workers' earnings. Remittance-dependent families and communities will likely experience a "cost reduction" and "lower consumption" effect, which will create economic problems in their country of origin.

Contrary to previous forecasts of a significant reduction in private remittances due to the COVID crisis (the World Bank predicted an annual decline of 14\%), between January-August 2020 in Ukraine, the decrease was only $6.4 \%{ }^{17}$ However, the data of the external sector statistics of the NBU show even an annual increase in remittances of international migrants to Ukraine. Despite the spring wave of migrant returns (at the beginning of the pandemic) and further difficulties in their countries of employment, Ukrainian migrant workers continue to do everything possible and impossible in order to support their families.

17 Face to face with migration in Ukraine. Central and Eastern Europe, International Labour Organization, 18.12.2020, https://www.ilo.org/budapest/whats-new/ WCMS_764754/lang--en/index.htm (access 28.05.2021). 


\section{Monetary Transfers of Migrants as a Way to Overcome the Economic Recession in Ukraine}

When analysing a sample of data on migrant remittances and indicators that characterise the business cycle of the economy for 1999$2020,{ }^{18}$ the correlation coefficient demonstrates the close relationship between business cycles in Ukraine and the main destination countries for Ukrainian migrants (Table 2). This confirms the common opinion about the excessive dependence of the Ukrainian economy on external conditions. However, migrant transfers do not show a significant link with internal and external cycles. In addition, the corresponding coefficients are negative, which may indicate both acyclic and countercyclical migrant transfers in comparison to business cycles. If we measure migrant transfers not in absolute terms, but as a percentage of GDP, the results are similar.

Table 2. Correlation Between Migrant Transfers and Business Cycles (deviation in $\%$ from the equilibrium trend)

\begin{tabular}{|l|c|c|c|}
\hline & $\mathrm{MT}_{\mathrm{t}}$ & $\mathrm{GDP}_{\mathrm{t}}$ & $\mathrm{IP}_{\mathrm{t}}$ \\
\hline Migrant transfers $\left(\mathrm{MT}_{\mathrm{t}}\right)$ & 1 & -0.04 & -0.23 \\
\hline GDP in Ukraine $\left(\mathrm{GDP}_{\mathrm{t}}\right)$ & -0.04 & 1 & 0.82 \\
\hline $\begin{array}{l}\text { Industrial production of countries receiving } \\
\text { Ukrainian migrants }\left(\mathrm{IP}_{\mathrm{t}}\right)\end{array}$ & -0.23 & 0.82 & 1 \\
\hline
\end{tabular}

Source: own elaboration based on the State Statistics Service of Ukraine.

To determine the relationship between the variables we use a regression model with error correction. In the first stage, the functional dependencies for the levels are estimated, and in the second stage, the short-term dynamics of the dependent variables are estimated using the residual terms of the corresponding equations.

The model used looks like this:

$$
\begin{aligned}
& \mathrm{Y}_{\mathrm{t}}=\mathrm{c}_{0}+\sum_{i=1}^{n} \alpha_{i} Y_{t-i}+\sum_{k=1}^{m} \sum_{j=0}^{p} \beta_{k, j} M_{k, t-1}+z_{t} \\
& \mathrm{y}_{\mathrm{t}}=\mathrm{c}_{1}+\sum_{i=1}^{n} a_{i} y_{t-i}+\sum_{k=1}^{m} \sum_{j=0}^{p} b_{k, j} m_{k, t-1}+d_{1} z_{t}+\mu_{t}
\end{aligned}
$$

where $c_{0}, c_{1}$ - constants, $M_{t}$ - vector of $m$ independent variables, $z_{t}, \mu_{t}-$ residual terms of the corresponding regression equations,

In equation (1) the coefficients $\alpha_{i}-\beta_{j}$ reflect the long-term relationship between the dependent and independent variables, and in equation (2) the

18 State Statistics Service of Ukraine, http://www.ukrstat.gov.ua/ (access 30.05.2021). 
coefficients $a_{i}-b_{j}$ characterise the short-term dependencies. The inclusion of the residual term $z_{t-1}$ from equation (1) in equation (2) allows one to obtain more accurate estimates of regression coefficients that take into account the influence of long-term trends on the short-term dynamics of the studied indicators. Both their relative indicator (\% of GDP) and cyclical deviations from the equilibrium trend can be used to assess the impact of migrant transfers.

The relationship between the cyclical position of GDP (the deviation from the equilibrium trend) and migrant transfers was estimated using the twostep least squares method for quarterly data for 1999-2020. We used a system of two regression equations with two endogenous variables - cyclical income dynamics and migrant transfers. The impact of migrant transfers was taken into account in two dimensions, using both relative (\% of GDP) and cyclical indicators (deviation in \% from the equilibrium trend).

The results were as follows:

$$
\begin{aligned}
& \begin{aligned}
G D P_{t}= & 0,589 G D P_{t-1}-0,902 M T_{t-1}+0,951 M T_{t-3}+0,472 I P_{t-1}-1,734 \text { recession (3a) } \\
& \left(8,402^{\star}\right) \quad\left(-1,99^{\star \star}\right)\left(2,51^{\star \star}\right)\left(4,35^{\star}\right)\left(-2,74^{\star}\right)
\end{aligned} \\
& \mathrm{R}^{2}=0,89 \mathrm{DW}=1,77 \mathrm{ADF}=-6,02 \\
& R E M_{t}=0,991 M T_{t-1}-0,026 G D P_{t-3}+0,048 I P_{t} \\
& \quad\left(61,01^{\star}\right) \quad\left(-1,77^{\star \star \star}\right) \quad(1,35) \\
& \mathrm{R}^{2}=0,69 \mathrm{DW}=2,04 \quad \mathrm{ADF}=-8,01^{\star}
\end{aligned}
$$

where $G D P_{t}$ is the deviation of Ukrainian GDP from the equilibrium trend (\%), $M T_{t}$ is the transfer of migrants (\% of GDP), $I P_{t}$ is the deviation from the equilibrium trend of industrial production of the most important countries accepting Ukrainian migration $(1994=100)$, recession is a dummy variable reflecting the impact of crisis phenomena (2004Q42005Q2, 2008Q4-2010Q4, 2014 Q3-2015 Q4, 2019 Q4-2020 Q4- 1, and other quarters -0 ).

Revenues from workers abroad initially reduce the deviation of GDP from the equilibrium trend, i.e. remittances of migrants have a stabilising character, but with a lag of three quarters, there is a clearly an opposite effect. This feature may mean that in the crisis of 2008-2010 increased migrant transfers helped to overcome the effects of the global financial crisis, and further strengthened the dynamics of GDP. The same is true in current times during the crisis caused by the COVID-19 pandemic. On the other hand, the revival of GDP leads to a decrease in migrant transfers (with a lag of three quarters), which may be due to reduced incentives for labour migration. 
Business cycles in Ukraine are quite synchronised with cyclical changes in countries that receive Ukrainian migrant workers. On the other hand, the coefficient $I P_{t}$ of influence on migrant transfers is positive but statistically insignificant. This means that the economic downturn of 2008-2009 and 2020-2021 in the world economy came amid a simultaneous slowdown in Ukrainian economicgrowth, but, contrary to expectations, migrant transfers almost did not decrease (it's expected that a decline in production, rising unemployment, and falling wages might be accompanied by a decrease in the income of migrant workers abroad). Predictably, during crisis periods, GDP falls below the equilibrium level (dummy variable recession), but no impact of this process on migrant transfers has been identified. This may mean that income from workers abroad responds to GDP dynamics rather than a sense of economic crisis in society.

Estimates of short-term dynamics reveal significant differences from the estimated long-term dependencies (3a) and (3b):

$$
\begin{aligned}
g d p= & 0,505 g d p_{t-1}-0,994 m t_{t-1}+0,479 m t_{t-3}+0,889 i p_{t-1}-0,767 z_{t-1} \\
\left(3,71^{\star}\right) & \left(-3,05^{\star}\right) \quad(1,51) \quad\left(4,62^{\star}\right)\left(-3,98^{\star}\right) \\
\mathrm{R}^{2}= & 0,78 \mathrm{DW}=2,08 \mathrm{ADF}=-7,24^{\star} \\
m t_{t}= & 0,085 g d p_{t-3}-0,079 i p_{t-4}-0,602 z^{\prime}{ }_{t-1} \\
& \left(1,78^{\star \star \star}\right) \quad\left(-1,67^{\star \star \star}\right) \quad\left(-4,01^{\star}\right) \\
\mathrm{R}^{2}= & 0,33 \mathrm{DW}=1,87 \mathrm{ADF}=-6,83^{\star}
\end{aligned}
$$

where $z_{t-1}$ and $z_{t-1}^{\prime}$ are forecast errors for the business cycle in Ukraine and the migrant transfers.

First, the restrictive impact of migrant transfers is clearer. Short-term coefficients of the impact of migrant transfers on the cyclical dynamics of income generally correspond to long-term dependences on the lag structure of functional impact, but the obtained estimates differ in favour of limited impact; in addition, the positive coefficient at $\mathrm{mt} \mathrm{t}-3$ is not statistically significant. At the same time, the cyclical increase in income leads to an increase in migrant transfers.

The direct dependence of income dynamics on the business cycle abroad remains unchanged, but there are weak signs of feedback for migrant transfers (the coefficient of $i p_{t-4}$ was significant at $10 \%$ ). In both cases - for income and migrant transfers - long-term dependencies are adjusted fairly quickly (4a), (4b).

If we use the cyclical indicator of migrant transfers for the study, the lack of stabilising impact of migrant transfers is more clearly observed, although the stimulation of income dynamics remains: 


$$
\begin{aligned}
& G D P_{t}=0,502 G D P_{t-1}+1,347 R M T_{t-3}+0,702 I P_{t-1}-1,301 \text { recession } \\
& \left(4,63^{\star}\right) \quad\left(1,98^{\star \star}\right)\left(3,83^{\star}\right)\left(-1,69^{\star \star \star}\right) \\
& \mathrm{R}^{2}=0,81 \mathrm{DW}=1,45 \mathrm{ADF}=-5,63^{\star} \\
& R M T_{t}=0,367 R M T_{t-1}+0,101 G D P_{t}-0,079 I P_{t} \\
& \left(2,78^{\star}\right) \quad(1,12) \quad\left(-1,689^{\star \star \star}\right) \\
& \mathrm{R}^{2}=0,29 \mathrm{DW}=2,21 \mathrm{ADF}=-6,13^{\star}
\end{aligned}
$$

where $R M T_{t}$ is the deviation of migrant transfers from the equilibrium trend ( $\%$ of GDP).

The use of the cyclical indicator of migrant transfers confirms more convincingly the conclusion about the destabilising impact of migrant transfers. An increase in migrant transfers by one percentage point above the equilibrium trend leads to a cyclical deviation of GDP by $1.2 \%$. For Ukrainian conditions, it is logical to assume that migrant transfers were used mainly for the purchase of housing under the financial market restrictions when households did not have the opportunity to obtain mortgage loans. It is also possible that in some cases, future transfers of migrants served as a kind of collateral in the provision of such loans to family members where there were sources of income from workers abroad.

With the change in the specification of the migrant transfers, the dependence on the domestic business cycle is lost, but at the same time there is an inverse dependence on the business cycle of the countries that accept migrants. This result means that the increasing transfers from migrants working abroad in 2008-2009 were the result not so much of altruistic considerations of supporting one's own families in Ukraine, but of deteriorating prospects abroad, which called into question the use of earned funds for permanent accommodation in host countries (including further emigration from Ukraine of family members and their integration in a foreign environment). The residues of equations (5a) and (5b) were used to estimate the short-term dependences:

$$
\begin{aligned}
g d p_{t}= & 0,412 g d p_{t-1}+0,687 r m t_{t-1}-1,003 i p_{t-1}-0,815 z^{\prime}{ }_{t-1} \\
& \left(2,177^{\star}\right)\left(1,68^{\star \star \star}\right) \quad\left(3,99^{\star}\right)\left(-4,02^{\star}\right) \\
\mathrm{R}^{2}= & 0,65 \mathrm{DW}=1,09 \mathrm{ADF}=-5,34^{\star} \\
r m t_{t}= & 0,057 g d p_{t-3}-0,087 i p_{t}-0,774 z^{\cdots}{ }^{t-1} \\
& \left(2,73^{\star}\right) \quad\left(-1,82^{\star \star \star}\right) \quad\left(-5,58^{\star \star}\right) \\
\mathrm{R}^{2}= & 0,35 \mathrm{DW}=1,96 \mathrm{ADF}=-7,40^{\star}
\end{aligned}
$$


where $z^{\prime}{ }_{t-1}$ and $z{ }^{\prime \prime}{ }_{t-1}$ are the forecast errors for the business cycle in Ukraine and the migrant transfers.

High coefficients of $z^{\prime \prime}{ }_{t-1}$ and $z^{\prime \prime}{ }_{t-1}$ testify to the effective correction of long-term dependences (6a), (6b). Short-term dependencies generally reproduce long-term relationships, but there are some important differences. First, the dependence on the business cycle of the countries receiving Ukrainian labour migrants disappears. Second, there is a direct link between the domestic business cycle and migrant transfers. It should also be noted that there is no autoregressive dependence for migrant transfers. This means that in the short term, income from workers abroad depends on the current situation and can be extremely volatile.

The pro-cyclical impact of migrant transfers is manifested primarily in the use of trend-free data when estimating long-term ratios. Short-term estimates also preferably support a similar conclusion. In the long run, migrant transfers react neutrally to Ukrainian GDP growth. At the same time, short-term effects can be considered pro-cyclical.

Thus, the analysis of the regression model makes it possible to lean in favour of the investment hypothesis of migrant transfers, when an increase in income from workers abroad should be expected during an economic boom. For specific Ukrainian conditions, this dependence is easy to explain by the use of migrant transfers to purchase real estate. The short-term dynamics of both indicators - cyclical changes in GDP and migrant transfers - are promptly adjusted under the existing long-term dependencies.

The growth of industrial production in the host countries, in the long run, does not lead to an increase in migrant transfers (in the model with a cyclical indicator, the corresponding coefficient becomes negative). In the short term, the cyclical increase in income abroad is reflected in a slowdown in the dynamics of migrant transfers to the Ukrainian economy. Estimates of short-term ratios clearly demonstrate that the cyclical increase in income abroad is reflected in a slowdown in the dynamics of remittances to Ukraine's economy. This can be considered as one of the explanations for the decrease in remittances between 2011-2013, as the stagnation of economic activity was observed in the countries which were the largest acceptors of Ukrainian labour migration (Greece, Spain, Italy, and Portugal). The clear dependence of the business cycle in Ukraine on the cyclical dynamics in foreign markets has been confirmed.

The crises in the world economy in 2008-2009 and 2020 were characterised by a decline in GDP but did not affect migrant transfers. At the same time, an increase in industrial production does not lead to an increase in migrant transfers. It can be concluded that accelerating 
economic growth alone is not enough to reduce labour migration from Ukraine.

Researchers have found a clear pro-cyclical impact of migrant transfers for Poland and Slovakia, which is seen against the background of income stimulation by transfers from workers abroad. In Romania, migrant transfers do not respond to the business cycle. ${ }^{19}$

It is also worth noting a number of issues related to migrant remittances during the COVID crisis, which require more detailed research, the most important of which are-how has the sectoral structure of remittances been changed due to the pandemic? If the overall volume of remittances did not experience a decrease, does it mean that Ukrainian labour migration is distributed among those sectors of the economies of host countries that have not suffered from COVID-19?

\section{Conclusions}

The COVID crisis has significantly reduced the number of international migrants; according to preliminary estimates, there has been a drop of $27 \%$. International migration processes during the COVID crisis are characterised by the following features: a low demand for labour, and the consequent decrease in employment; persistent severe travel restrictions; and declining income.

The COVID-19 pandemic has hit many industries harder than the 2008 financial crisis, and most industries will need more time to recover. Significant remittances from migrant workers mitigate the effects of crises on labour-donor countries.

Today, EU Member States constitute the largest region for the employment of migrants from Ukraine. In general, more than $60 \%$ of remittances come to Ukraine from EU countries. Contrary to previous forecasts of a significant decline in private remittances due to the coronavirus crisis, NBU external sector statistics show an annual increase in remittances from international migrants to Ukraine.

As a result of the calculations, the strong dependence of the Ukrainian economy on the dynamics of foreign markets has been confirmed. Estimates of long-term ratios reveal the pro-cyclical impact of migrant transfers, especially when using trend-free data. Revenues from people working abroad initially reduce GDP deviations from the equilibrium trend, but over time there is a clear pro-cyclical impact. This feature is

19 Y. Demianchuk, Stabilizaciinui vplyv pryvatnykh transfertiv u transformaciinykh ekonoтikakh (Стабілізачійний вплив приватних трансфертів у трансформащійних економіках), Natsionalnyi Universytet im. Ivana Franks, Lviv 2014, p. 20. 
favourable for the Ukrainian economy and may mean that during the crisis, increased migrant transfers helped to overcome the effects of the global crisis.

Among some functional impact mechanisms, an increase in migrant remittances is useful for increasing bank deposits and lending in the national currency, while the impact on foreign currency lending has been limited. So far in Ukraine there is no connection between migrant remittances and budget revenues, which can be explained by the insufficient investment orientation of the migrants' funds, but at the same time there are no opportunities to increase tax revenues.

To improve the investment climate in the context of the COVID crisis in Ukraine, it is advisable to link at least part of the remittances through joint public-private projects which, in turn, will serve to expand infrastructure in rural areas, as practiced in some countries (such as Mexico) and will allow the use of funds earned abroad for the development of small and medium-sized businesses, and will weaken the incentives for their use to increase imports of consumer goods.

\section{References}

Bakker M., Migrating into Financial Markets: How Remittances Became a Development Tool, University of California Press, Oakland 2015.

Barajas A., et. al., Do Workers' Remittances Promote Economic Growth?, IMF Working Paper WP/09/153, International Monetary Fund Washington 2009.

Berger R., Latest update of our corona economic impact series, https://www. rolandberger.com/en/Insights/Publications/This-crisis-is-differentComparing-the-coronavirus-crisis-with-the-financial.html (access 2.06.2021).

Demianchuk Y., Stabilizaciinui vplyv pryvatnykh transfertiv $u$ transformaciinykh ekonomikakh (Стабілізаційний вплив приватних трансфертів y трансформаційних економіках), Natsionalnyi Universytet im. Ivana Franko, Lviv 2014.

Face to face with migration in Ukraine. Central and Eastern Europe, International Labour Organization, https://www.ilo.org/budapest/ whats-new/WCMS_764754/lang--en/index.htm (access 28.05.2021).

Global Migration Growth Slowed by 27 Per Cent in 2020, Following Decades of Robust Increase, Annual Report Finds. United Nations. Meetings Coverage and Press Releases, https://www.un.org/press/en/2021/dev3436.doc.htm (access 7.06.2021). 
Levtsun O., Zovnishnia trudova mihraciia v Ukraini jak demohrafichna problemа (Зовнішня трудова міграчія в Україні як демограбічна проблема), http://www.hearts.in.ua/articles/job_search/694.php (access 11.06.2021).

Migration and Remittances: Eastern Europe and the Former Soviet Union, eds. A. Mansoor, B. Quillin, World Bank, Washington 2009.

Natsionalnyi bank Ukrainy. Statystyka zovnishnioho sektoru (Національний банк України. Статистика зовнішнього сектору), https://bank.gov. ua/ua/statistic/sector-external/data-sector-external (access 28.05.2021). OECD Policy Responses to Coronavirus (COVID-19) What is the impact of the COVID-19 pandemic on immigrants and their children?, OECD, 19.10.2020, http://www.oecd.org/coronavirus/policy-responses/whatis-the-impact-of-the-covid-19-pandemic-on-immigrants-and-theirchildren-e7cbb7de/ (access 30.07.2021).

State Statistics Service of Ukraine, http://www.ukrstat.gov.ua/ (access 30.05.2021).

Tokarchuk T., Perekazy vid trudovykh mihrantiv: potochna sytuaciia ta ocinka perspektyv. Natsionalnyi bank Ukrainy (Перекази від трудовихмігрантів: поточна ситуачія та оиінка перспектив. Національнийбанк України), https://bank.gov.ua/admin_uploads/article/Transfers_from_migrant_ workers_Tokarchuk_2020-06-03.pdf?v $=4$ (access 2.06.2021).

Zakha D., Luke M., Kincia-kraiu ne vydno: trudova mihraciia z Ukrainy mozhe spovilnytysia, prote, shvydshe za vse tryvatyme (Кіния-краюо не видно: трудова міграціл з України може сповільнитися, проте, швидше за все, триватиме), https://voxukraine.org/uk/kintsya-krayu-ne-vidnotrudova-migratsiya-z-ukrayini-mozhe-spovilnitisya-prote-shvidsheza-vse-trivatime/ (access 8.06.2021).

Zanuda A., Mihranty chy investory: hto bilshe vklade v ekonomiku Ukrainy (Мігранти чи інвестори: хто більще вкладає в економіку України?), BBC Ukraina, https://www.bbc.com/ukrainian/features-45473686 (access 1.06.2021).

Zvarych R., Tysh T., Upravlinnia kryzovymy sytuaciiamy ta liderstvo vumovakh koronakryzy (Управління кризовими ситуацілми та лідерство в умовах коронакризи), „Visnyk Ternopilskoho natsionalnoho ekonomichnoho universytetu", no. 2/2020, http://visnykj.wunu.edu.ua/index.php/ visnykj/article/download/1108/1213 (access 8.06.2021). 